\title{
MOLECULAR DYNAMICS SIMULATION OF Ti-6Al-4V DIFFUSION BONDING BEHAVIOR UNDER DIFFERENT PROCESS PARAMETERS
}

\author{
SIMULACIJA MOLEKULARNE DINAMIKE ZLITINE Ti-6Al-4V, \\ DIFUZIJSKO ZVARJENE PRI RAZLIČNIH PROCESNIH POGOJIH
}

\author{
Xiaogang Liu*, Lei Xu, Sun Zhang \\ Jiangsu Province Key Laboratory of Aerospace Power Systems, College of Energy and Power Engineering, \\ Nanjing University of Aeronautics and Astronautics, Nanjing 210016, China \\ Prejem rokopisa - received: 2019-07-25; sprejem za objavo - accepted for publication: 2020-01-29
}

doi: $10.17222 /$ mit.2019.172

\begin{abstract}
In this paper the diffusion-bonding process of a titanium alloy was investigated in detail using molecular dynamics. The protocell model of a Ti-6Al-4V alloy was obtained by the atomic random substitution method. The mixed potential function method, EAM (Embedded Atom Method) and Morse potential was used to deal with the Ti-Al-V ternary alloy system. And the diffusion bonding process of Ti-6Al-4V was simulated numerically. The influence of temperature, pressure and holding time on the diffusion bonding behavior of Ti-6Al-4V alloys was studied. The results showed that an increase of the temperature, pressure and holding time can improve the diffusion of interfacial atoms and increase the diffusion bonding width. In addition, the diffusion temperature has a critical value, i.e., $1100 \mathrm{~K}$. When the temperature is lower than $1100 \mathrm{~K}$, the interface atoms hardly diffuse. The MSD (Mean Square Deviation) vs. $t$ curves of Ti, Al and V atoms at different temperatures were established. The diffusion coefficients of Ti, Al and $\mathrm{V}$ atoms at different temperatures were obtained by the relationship between the MSD and the atomic diffusion coefficient, after which the Arrhenius equations of the diffusion coefficient were obtained, respectively. Based on the diffusion coefficient equation, the diffusion activation energies of each element were deduced. Compared with the experimental data, the rationality of the simulation results was verified
\end{abstract}

Keywords: molecular dynamics, Ti-6Al-4V alloy, diffusion bonding, diffusion coefficient

$\mathrm{V}$ članku avtorji natančno opisujejo raziskavo procesa difuzijskega varjenja (spajanja) Ti zlitine z uporabo metode molekularne dinamike. Protocelični model Ti-6Al-4V zlitine so avtorji dobili z metodo naključne metode nadomeščanja (substitucije). Za obdelavo ternarnega zlitinskega sistema Ti-Al-V so uporabili mešano potencialno funkcijsko metodo, metodo EAM (angl.: Embedded Atom Method, ta upošteva potencial med atomi) in Morsejev potencial. Proces difuzijskega spajanja Ti-6Al-4V so avtorji simulirali numerično. Studirali so vpliv temperature, tlaka in časa zadrževanja na difuzijsko spajanje Ti-6Al-4V zlitin Rezultati simulacij so pokazali, da povišanje temperature in tlaka, ter podaljšanje časa zadrževanja lahko izboljša difuzijo med atomi in tako poveča širino difuzijskega spoja. Dodatno so ugotovili, da je kritična temperatura $1100 \mathrm{~K}$. Pod to temperaturo medatomarna difuzija poteka težko (počasi). Avtorji so ugotovili odvisnost kvadratnega korena povprečnega odstopanja (MSD; angl.: Mean Square Deviation) od časa $t$ za Ti, Al in V atome pri različnih temperaturah. Difuzijske koeficiente za Ti, Al in V atome pri različnih temperaturah so določili s povezavo med MSD in atomskimi difuzijskimi koeficienti oziroma določili so njihove difuzijske koeficiente v obliki Arrheniusove enačbe. Na osnovi enačb za difuzijske koeficiente so določili aktivacijsko energijo za difuzijo vsakega posameznega kemijskega elementa. Na koncu so še preverili ujemanje rezultatov simulacij z eksperimentalnimi podatki.

Ključne besede: molekularna dinamika, zlitina Ti-6Al-4V, difuzijsko spajanje (varjenje), difuzijski koeficient

\section{INTRODUCTION}

The Ti-6Al-4V alloy is an important manufacturing material in the aviation field because of its excellent comprehensive properties. At present, the titanium alloy wide-chord hollow fan blade formed by superplasticforming/diffusion-bonding technology has become one of the key technologies of advanced aero-engines. However, the diffusion bonding zone is very narrow, usually at the micron level. It is difficult to study the performance of joints from a macroscopic point of view by conventional methods. It is a satisfactory method to study the diffusion bonding process by molecular dynamics.

*Corresponding author's e-mail:

liuxg03@nuaa.edu.cn (Xiaogang Liu)
B. J. Alder et al. ${ }^{1}$ first put forward the classic molecular dynamics theory in 1957 and proved the rationality of the theory through the "hard sphere" liquid model, thus starting the prelude of molecular dynamics simulation research. Subsequently, a large number of researchers continued to develop the method. L. Verlet ${ }^{2}$ proposed the frog-leaping algorithm, which has been used today because of its fast calculation speed and small storage capacity. C. H. Andersen, ${ }^{3}$ D. J. Evans et al. ${ }^{4}$ developed the constant-pressure control method and the temperature control method for a non-equilibrium system to improve the molecular dynamics method. Based on electronic theory, R. Car ${ }^{5}$ supplemented and explained molecular dynamics methods in principle and successfully expanded the research field of molecular dynamics methods. In recent years, with the rapid 
development of computer technology, molecular dynamics as an effective simulation method in the field of computational materials has attracted the attention of researchers. M. Grujicic ${ }^{6}$ used the EAM potential to simulate the martensitic transformation process of a Ti-V alloy and analyzed the transformation mechanism of the lattice structure. L. Long et al. $^{7}$ simulated the diffusion process of $\mathrm{Cu}-\mathrm{Al}$ heterogeneous alloys using the molecular dynamics method, indicating that the diffusion process was mainly caused by the diffusion of $\mathrm{Cu}$ atoms into Al. The diffusion bonding process of Ti-Al heterogeneous alloys was simulated using LAMMPS software and the influence of surface roughness on the diffusion effect was also analyzed by T. Fuling. ${ }^{8}$ L. L. Zhu ${ }^{9}$ studied the diffusion process of $\mathrm{V}$ atoms in a Ti alloy to find the influence of the $\mathrm{V}$ atom concentration on the diffusion distance and the diffusion coefficient.

In summary, a lot of research work had been done on the structural transformation and diffusion process of binary alloys using the molecular dynamics method. However, the molecular dynamics simulation of the diffusion-bonding process between ternary alloys is less involved. In the paper the diffusion-bonding process of the Ti-6Al-4V ternary alloy was simulated using molecular dynamics. The influence of the process parameters on the diffusion bonding width and the atomic diffusion coefficient of alloys were analyzed in detail.

\section{FUNDAMENTALS OF THE DIFFUSION-BONDING SIMULATION BY MOLECULAR DYNAMICS}

The atoms vibrate around their equilibrium sites due to the exchange of the chemical potential and atomic energy that overcome the barrier migrated to the location of the adjacent atom. The atomic migration process of micro and macro arising from the phenomenon is called diffusion. Diffusion-bonding technology relies on the local plastic deformation of the material surface at high temperature and high pressure to realize bonding on the atomic scale by the diffusion of the bonded materials on the surface. ${ }^{10}$ This process contains very complex physical and chemical reactions. Therefore, it is very important to understand comprehensively the basic law of the diffusion of metal atoms and the geometric model of diffusion bonding.

In the molecular dynamics model, atoms are usually approximated as particles or compact pellets. The motion state of any particle can be obtained by integrating Newton's motion equation, ${ }^{11}$ where the differential equation of Newton's second law is expressed as:

$$
m_{i} \frac{\mathrm{d}^{2} r_{i}}{\mathrm{~d} t^{2}}=-\nabla_{i} V\left(r_{1}, r_{2}, \ldots, r_{n}\right)
$$

where $m_{i}$ and $r_{i}$ are the mass and position parameters of the number $i$ atom, respectively. $\mathrm{V}\left(r_{1}, r_{2}, \ldots r_{n}\right)$ is the potential function of the atom.
The trajectory of the system can be described by calculating the particle's velocity and position according to Equation (1). By averaging the calculated results of the system with a statistical method, the required macroscopic parameters such as temperature, pressure and stress can be further obtained. In addition, the microscopic structure of the particles can also be investigated intensively.

In molecular dynamics simulations the interaction between different atoms is expressed by the potential function, which defines the relationship between atomic potential energy and the coordinates. ${ }^{12}$ The main potential functions are the Lennard-Jones(L-J/n-m) potential, the Morse potential, the Tersoff-Brenner potential, the Embedded Atom Method (EAM) potential, the Sutton-Chen potential and so on. ${ }^{6}$ Among them, the Morse potential is a typical pairing potential function, which is widely used in metals and alloys. It has a high accuracy in simulating metallic systems with FCC or HCP structures. ${ }^{13}$ The Morse potential function is expressed as follows in Equation (2): ${ }^{14}$

$$
V_{i j}=D_{0}\left\{\exp \left[-2 \alpha\left(r_{i j}-r_{0}\right)\right]-2 \exp \left[-\alpha\left(r_{i j}-r_{0}\right)\right]\right\}
$$

where $D_{0}$ has an energy dimension to describe the strength of the interactions between atoms. The $r_{0}$ is the mean radius and $\alpha$ is the normalized coefficient.

The EAM is a typical multi-body potential function. It takes into account the free electron gas effect of each atom's local region. The gel model is used to simplify the description of the complex environment around the atoms. ${ }^{15,16}$ It can be expressed as:

$$
\begin{gathered}
U_{\text {total }}=\sum_{i} F\left(\rho_{i}\right)+\frac{1}{2} \sum_{i} \sum_{j \neq i} \varphi\left(r_{i j}\right) \\
\rho_{i}=\sum_{j \neq i} f\left(r_{i j}\right)
\end{gathered}
$$

where $F$ represents the atoms' embedded potential, which is a function of $\rho_{i}$. The function $\varphi$ is the shortrange pair potential $\rho_{i}$ is the function of the density of electrons in an atom. The first item at the right-hand end of Equation (4) is the energy required to embed atoms in the background of an electron mass. The second item is the traditional pairing potential that describes the repulsion between atoms in a solid system. According to Equations (3) and (4), it can be deduced that the interaction force between the atoms $i$ and $j$ is expressed as:

$$
F_{i j}=\left\{\left[F^{\prime}\left(\rho_{i}\right)+F^{\prime}\left(\rho_{j}\right)\right] f^{\prime}\left(r_{i j}\right)+\varphi^{\prime}\left(r_{i j}\right)\right\}
$$

At present, the EAM potential function of Ti-Al-V ternary alloys has not been systematically studied. In the paper, the mixed potential method is used. The EAM potential is used for the atoms Ti-Al and Al-V, while the Morse potential is used for the atoms Ti-V.

The process parameters such as holding temperature and pressure have an important influence on the quality 
of the diffusion bonding. The selection of the appropriate temperature- and pressure-control methods is an important step in the molecular dynamics simulation of diffusion bonding. In the paper, the Nose-Hoover thermostat method was used to control the temperature in the simulation process. ${ }^{4}$ The basic principle of this method is to introduce coordinate variables to realize the energy exchange between the atoms and the external thermostat. The Lagrange equation of the energy is expressed as:

$$
L_{\text {Nose }}=\sum_{i=1}^{N} \frac{m_{i}}{2} s^{2} r_{i}^{2}-U\left(r^{N}\right)+\frac{M}{2} \cdot \dot{s}^{2}-\frac{g}{\beta} \ln s
$$

When the system temperature agrees with $T>T_{\mathrm{c}}$, the atoms in the system transfer energy to the external thermostat and the velocity of the atoms decreases. Otherwise the system absorbs energy and the velocity of the atoms increases accordingly.

In a molecular dynamics simulation, the pressure of the system varies due to the collision and extrusion caused by the atomic vibration and the free movement. However, the Parrinello-Rahman control method is used to control the pressure conditions so as to maintain the constant pressure state of the system. ${ }^{17}$

\section{NUMERICAL SIMULATION OF THE DIFFUSION-BONDING PROCESS OF Ti-6Al-4V}

\subsection{Modeling}

In molecular dynamics, each atom in the initial model can be arranged in a given lattice coordinate. Therefore, the initial model can be accurately established

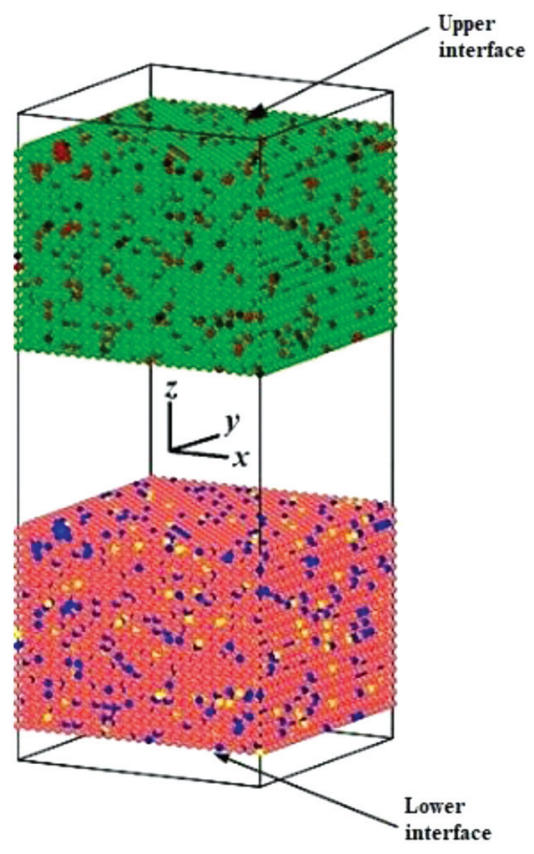

Figure 1: Ti-6Al-4V initial 3D model diagram in the direction of [001] (Green and pink are titanium atoms, blue and dark red are aluminum atoms, black and yellow are vanadium atoms) by knowing the coordinates of the lattice arrangement and the kinds of atoms located at each coordinate. Using the MATLAB program, a series of coordinate sites arranged strictly according to the lattice structure were generated. By calculating the percentage content of each constituent atom, the coordinate sites were randomly assigned to the atomic number according to the corresponding percentage by using the random substitution method. Thus, the proto-cell model was generated. The molecular dynamics model of an alloy system with any given structure and size could be generated by the method.

For Ti-Al-V ternary alloys, the numbers of Ti, Al and $\mathrm{V}$ atoms were set to 1,2 and 3, respectively. The initial three-dimensional model of the Ti-6Al-4V was set as an integrity BCC (body-centered cubic) structure. The axis $x, y$ and $z$ correspond to the orientations of [100], [010] and [001], respectively. The system of the proto-cell model was an NVT ensemble. The corresponding Ti atoms were randomly replaced by $10 \mathrm{a} / \% \mathrm{Al}$ and $3.6 \mathrm{a} / \%$ $\mathrm{V}$, respectively. The scale of the proto-cell model was $25 \times 25 \times 18$ (the Ti lattice constant is $0.328 \mathrm{~nm}$ ) and the total number of atoms was 43,236 . Among them, there were $37,154 \mathrm{Ti}$ atoms, $4516 \mathrm{Al}$ atoms and $1566 \mathrm{~V}$ atoms. The final atomic model was shown in Figure 1. In order to observe clearly the upper and lower models of the contact surface they were distinguished by different colors. The pressure loads were applied alone the $z$ direction of the boundary layer. Considering the scale effect, the periodic boundary conditions were set in the $x$ and $y$ directions and contractive boundary conditions were set in the $z$ direction.

\subsection{The influence of process parameters on the diffu- sion bonding width}

\subsubsection{Temperature}

The melting point of Ti-6Al-4V alloy is about $1900 \mathrm{~K}$. The temperature is an important factor that mainly affects the diffusion behavior of the atoms in the interface region for the diffusion-bonding process of materials. A higher holding temperature leads to a plastic yield at the diffusion-bonding interface, which will expand the contact area and promote the diffusion of atoms.

Figure 2 shows the atom distribution on the [010] crystal plane after complete diffusion at different holding temperatures. The atoms of the upper half model were set to white. The red, blue and yellow atoms were Ti, Al and V, respectively. As can be seen from Figure 2, the atomic diffusion distance increases, and the contact interface diffusion becomes more sufficient with an increase of the system temperature (from $1000 \mathrm{~K}$ to $1183 \mathrm{~K}$ ) under the conditions of constant pressure and holding time. During the diffusion process, the Ti matrix atoms near the interface migrate significantly. The concentration of $\mathrm{V}$ atoms in the alloy is slightly lower 

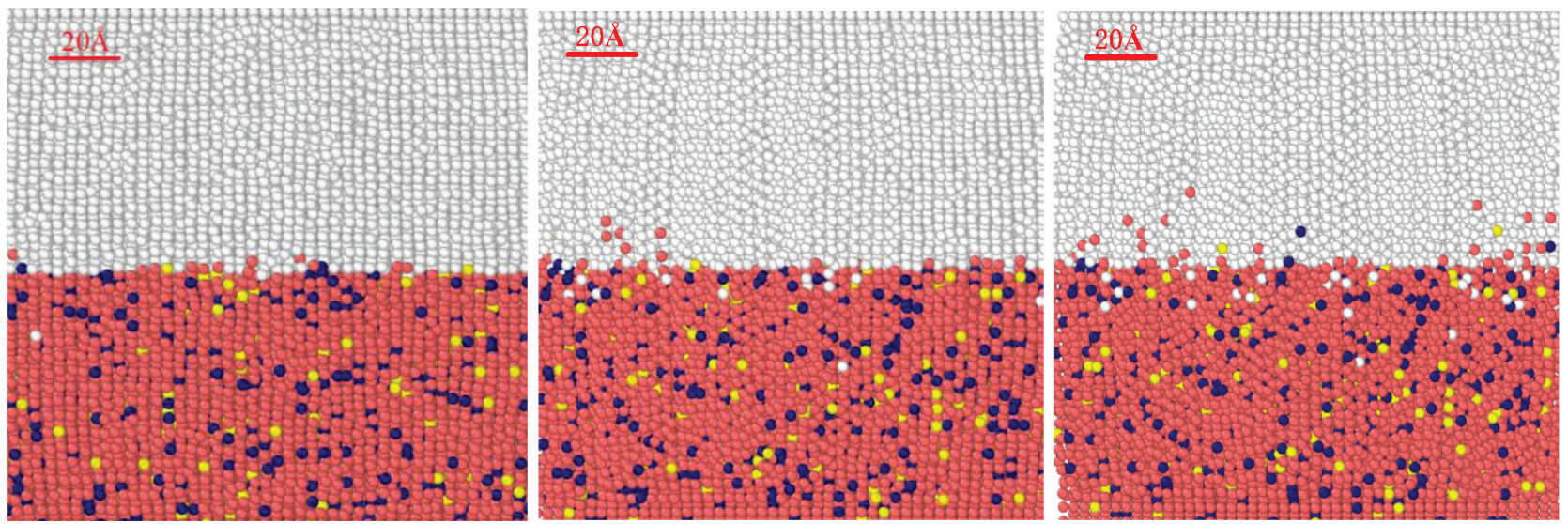

Figure 2 Atomic diffusion results at different temperatures $(P=3.5 \mathrm{MPa}, t=400 \mathrm{ps})$ : a) $T=1000 \mathrm{~K}$, b) $T=1100 \mathrm{~K}$, c) $T=1183 \mathrm{~K}$

than that of the $\mathrm{Al}$ atoms. It can also be seen from Figure 2 that the atoms on the interface hardly diffused below $1100 \mathrm{~K}$. It is indicated that the holding temperature should be higher than a critical value in order to obtain good quality of the diffusion-bonde jdoints.

The concentration distribution of different elements along the $z$ direction was obtained, as shown in Figure 3. Because the initial content of $\mathrm{V}$ was very small and the content of the diffusion-bonding layer was less, the atomic concentration of Ti-V was summed up. In Figure 3, the Ti-V1 and Al1 were model atoms below the contact surface, while Ti-V2 and A12 were model atoms above the contact surface. It was considered that the region where the concentration of $\mathrm{Ti}-\mathrm{V}$ atoms changes more than $5 \%$ is the diffusion bonding layer, as shown by the black dotted line region. It can be seen from Figure 3 that the width of the diffusion-bonding layer increases obviously with the increase of the holding temperature.

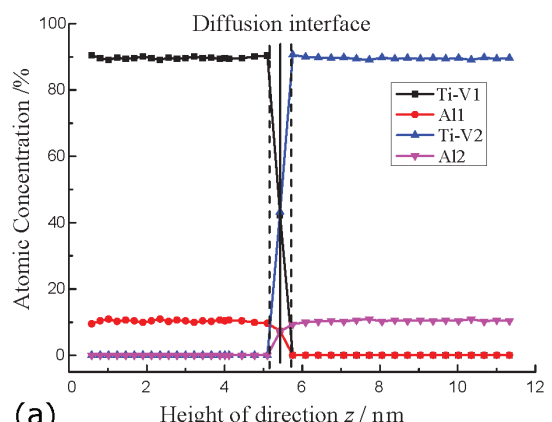

(a)
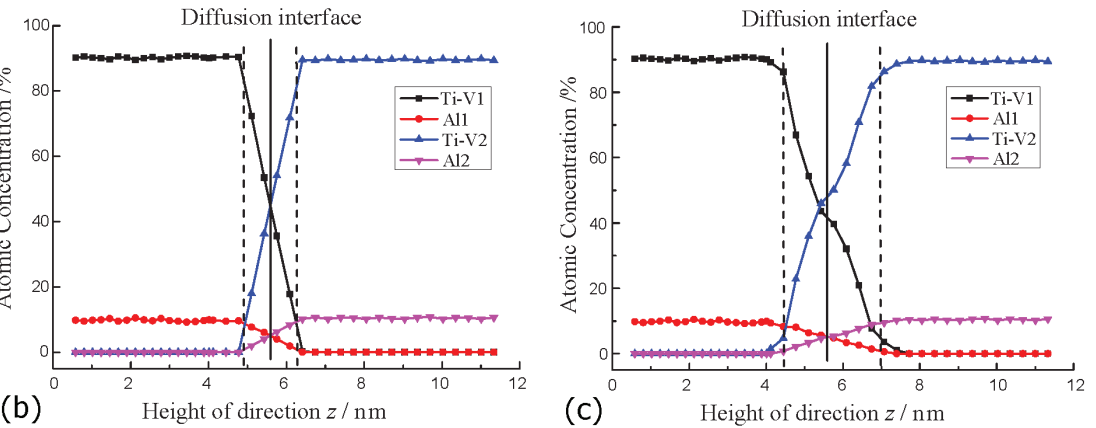

3: Atomic concentration
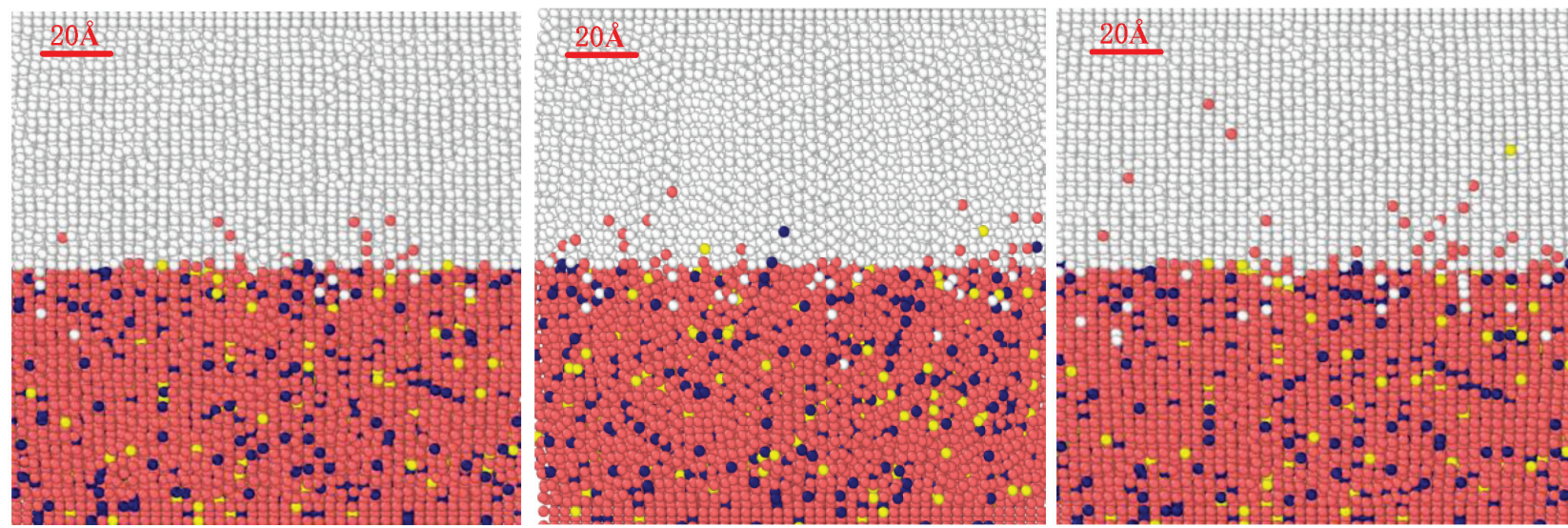

Figure 4: Atomic diffusion results at different pressure $(T=1183 \mathrm{~K}, t=400 \mathrm{ps})$ : a) $P=2.5 \mathrm{MPa}, \mathrm{b}) P=3.5 \mathrm{MPa}$, c) $P=4.5 \mathrm{MPa}$ 

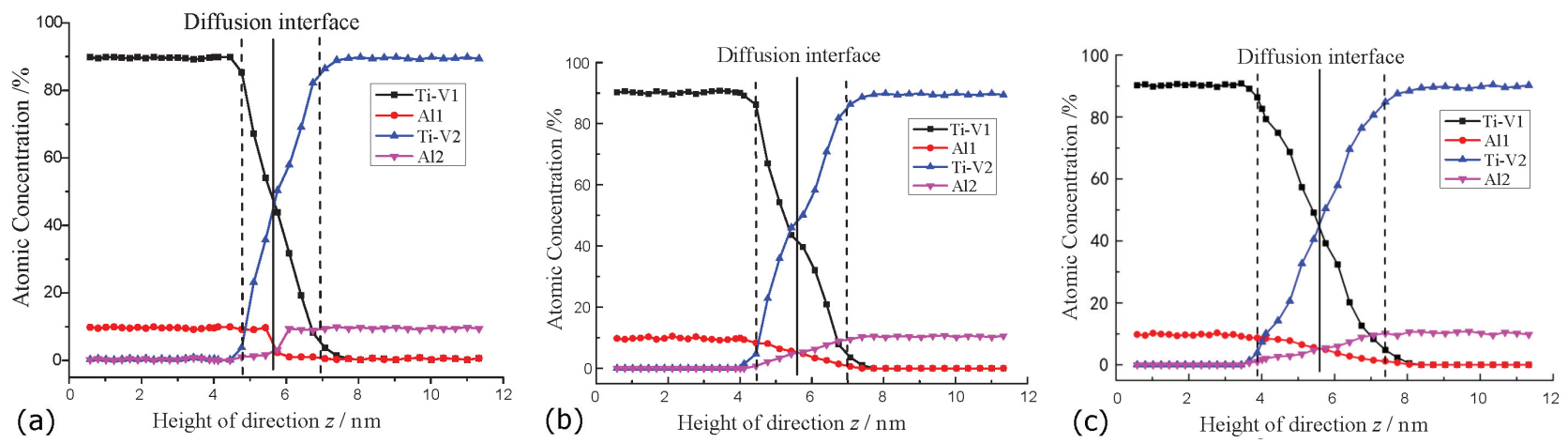

Figure 5: Atomic concentration distribution of Ti-Al-V after diffusion bonding at different pressures $(T=1183 \mathrm{~K}, t=400 \mathrm{ps})$ : a) $P=2.5 \mathrm{MPa}$, b) $P=3.5 \mathrm{MPa}$, c) $P=4.5 \mathrm{MPa}$

\subsubsection{Pressure}

A higher pressure can promote the plastic deformation of the interface, reduce the recrystallization temperature of the interface, and thus improve the quality of the diffusion bonding.

Figure 4 shows the atom distribution on the [010] crystal plane after complete diffusion under different pressures. It can be seen from Figure 4a that the atomic migration occurred obviously at the interface of the model at $P=2.5 \mathrm{MPa}$. When the pressure increased from 2.5 $\mathrm{MPa}$ to $4.5 \mathrm{MPa}$, the diffusion distance of the atoms along the depth direction increases and the diffusion becomes more sufficient.

Figure 5 shows the concentration distribution of Ti-Al-V along the $z$ direction after diffusion bonding under the condition of different pressures. It can be found that the width of the diffusion-bonding layer increases obviously with the increase of the pressure when the other process parameters are constant.

\section{SUMMARY OF THE INFLUENCE OF THE PROCESS PARAMETERS ON THE DIFFUSION BONDING WIDTH}

In order to investigate the influence of the process parameters on the diffusion-bonding width, the diffusion-bonding process of Ti-6Al-4V under different pressures, temperatures and holding times were simulated by molecular dynamics. A total of 48 cases were obtained, as shown in Table 1.

According to the simulation results for the diffusionbonding width in Table 1, the three-dimensional curved surfaces of the Ti-6Al-4V diffusion bonding width varying with pressure, temperature and holding time were obtained by polynomial fitting with MATLAB software, as shown in Figure 6. As can be seen from Figure 6, the pressure and holding time have little effect on the diffusion-bonding width below $1100 \mathrm{~K}$. Therefore, for the ideal model, the diffusion-bonding temperature of Ti-6Al-4V should be greater than $1100 \mathrm{~K}$. When the holding time was over 800 ps with constant pressure, the diffusion-bonding width increases first and
Table 1: Influence of process parameters on the diffusion-bonding width

\begin{tabular}{|c|c|c|c|c|}
\hline $\begin{array}{l}\text { Holding } \\
\text { time /ps }\end{array}$ & \begin{tabular}{|c|} 
Temperature \\
$/ \mathrm{K}$
\end{tabular} & $\begin{array}{l}\text { Pressure } \\
/ \mathrm{MPa}\end{array}$ & $\begin{array}{l}\text { Diffusion bong } \\
\text { width /nm }\end{array}$ & No. \\
\hline \multirow{12}{*}{200} & \multirow{3}{*}{1283} & 4.5 & 2.971 & 1 \\
\hline & & 3.5 & 2.324 & 2 \\
\hline & & 2.5 & 1.797 & 3 \\
\hline & \multirow{3}{*}{1183} & 4.5 & 1.865 & 4 \\
\hline & & 3.5 & 1.434 & 5 \\
\hline & & 2.5 & 1.288 & 6 \\
\hline & \multirow{3}{*}{1100} & 4.5 & 1.370 & 7 \\
\hline & & 3.5 & 0.912 & 8 \\
\hline & & 2.5 & 0.581 & 9 \\
\hline & \multirow{3}{*}{1000} & 4.5 & 0.764 & 10 \\
\hline & & 3.5 & 0.752 & 11 \\
\hline & & 2.5 & 0.214 & 12 \\
\hline \multirow{12}{*}{400} & \multirow{3}{*}{1283} & 4.5 & 4.407 & 13 \\
\hline & & 3.5 & 3.130 & 14 \\
\hline & & 2.5 & 2.825 & 15 \\
\hline & \multirow{3}{*}{1183} & 4.5 & 3.503 & 16 \\
\hline & & 3.5 & 2.646 & 17 \\
\hline & & 2.5 & 2.123 & 18 \\
\hline & \multirow{3}{*}{1100} & 4.5 & 1.689 & 19 \\
\hline & & 3.5 & 1.31 & 20 \\
\hline & & 2.5 & 0.744 & 21 \\
\hline & \multirow{3}{*}{1000} & 4.5 & 0.962 & 22 \\
\hline & & 3.5 & 0.880 & 23 \\
\hline & & 2.5 & 0.411 & 24 \\
\hline \multirow{12}{*}{800} & \multirow{3}{*}{1283} & 4.5 & 6.438 & 25 \\
\hline & & 3.5 & 5.899 & 26 \\
\hline & & 2.5 & 5.212 & 27 \\
\hline & \multirow{3}{*}{1183} & 4.5 & 4.871 & 28 \\
\hline & & 3.5 & 4.258 & 29 \\
\hline & & 2.5 & 3.241 & 30 \\
\hline & \multirow{3}{*}{1100} & 4.5 & 2.301 & 31 \\
\hline & & 3.5 & 1.721 & 32 \\
\hline & & 2.5 & 1.241 & 33 \\
\hline & \multirow{3}{*}{1000} & 4.5 & 1.322 & 34 \\
\hline & & 3.5 & 1.010 & 35 \\
\hline & & 2.5 & 0.872 & 36 \\
\hline \multirow{12}{*}{1200} & \multirow{3}{*}{1283} & 4.5 & 9.725 & 37 \\
\hline & & 3.5 & 8.833 & 38 \\
\hline & & 2.5 & 7.838 & 39 \\
\hline & \multirow{3}{*}{1183} & 4.5 & 6.335 & 40 \\
\hline & & 3.5 & 5.710 & 41 \\
\hline & & 2.5 & 4.968 & 42 \\
\hline & \multirow{3}{*}{1100} & 4.5 & 2.762 & 43 \\
\hline & & 3.5 & 2.471 & 44 \\
\hline & & 2.5 & 1.861 & 45 \\
\hline & \multirow{3}{*}{1000} & 4.5 & 1.738 & 46 \\
\hline & & 3.5 & 1.532 & 47 \\
\hline & & 2.5 & 1.291 & 48 \\
\hline
\end{tabular}




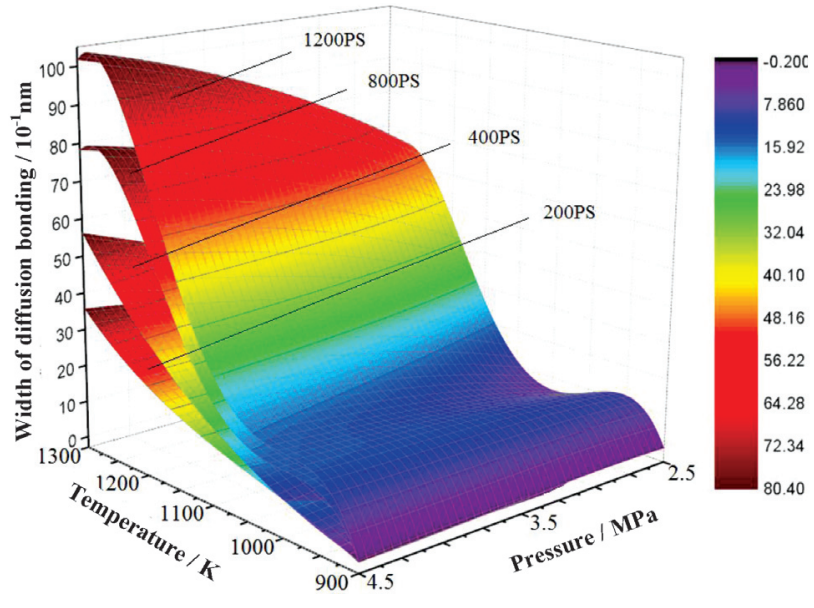

Figure 6: Variation of the diffusion-bonding width with the process parameters

then decreases slightly with an increase of the holding temperature. The optimum holding temperature is about $1200 \mathrm{~K}$, which is consistent with the actual temperature used in the Ti-6Al-4V diffusion bonding. In addition, it is clear that the influence of pressure on the diffusion bonding width became more and more significant with the increase of the holding temperature for a constant holding time. Therefore, in the actual diffusion-bonding process of titanium alloy, the full diffusion of atoms in the interface region can be promoted by increasing the holding temperature to $1200 \mathrm{~K}$, step by step, and increasing the pressure properly.

\subsection{The influence of temperature on the diffusion coefficient}

In a molecular dynamics simulation, the Mean Square Displacement (MSD) is normally used to analyze the change of the atomic trajectory with time. ${ }^{18}$ The dynamic information, such as the diffusion coefficient of the system, can be obtained. The main idea is to obtain instantaneous coordinates of the particles and solve the differential equations by recording the dynamic evolution process of particles at a certain temperature, so as to determine the MSD of the system. The Einstein function relationship between the MSD and the correlation time $t$ is shown as follows in Equation (7):

$$
\operatorname{MSD}(t)=\frac{1}{N} \sum_{i=1}^{N}\left\langle\left|r_{i}(t)-r_{i}(0)\right|^{2}\right\rangle
$$

where $N$ is the number of atoms in the simulation system, $r_{i}(t)$ is the position vector of the atom $i$ at time $t$, and $r_{i}(0)$ is the initial position vector of the atom $i$. When the system runs for long enough, the MSD limit formula can be expressed as:

$$
\lim _{t \rightarrow \infty} M S D(t)=c+2 \lambda D
$$

where, $\lambda$ is the dimension of the system, $D$ is the diffusion coefficient, and $c$ is a constant.

Equation (8) shows that in a three-dimensional system, $\lambda=3$, the diffusion coefficients of various elements can be obtained from the slope of the corresponding MSD distribution curve vs. time. Figure 7 shows the distribution curve for the MSD of Ti, Al and V under 1000-1500 K. It can be seen from the figure that the MSD of the $\mathrm{Ti}, \mathrm{Al}$ and $\mathrm{V}$ atoms shows a similar trend, i.e., it increases gradually with the increase of the temperature and shows an approximate linear relationship with the holding time. This indicates that the higher the temperature is, the higher the transition frequency of the $\mathrm{Ti}, \mathrm{Al}$ and $\mathrm{V}$ atoms is at the interface.

The diffusion coefficients of various atoms under different temperatures were obtained by fitting data from the MSD vs. time in Figure 7, as listed in Table 2. It can be found that the diffusion coefficient of a Ti atom is relatively high and that of an $\mathrm{Al}$ atom is the smallest at the same temperature. When the holding temperature is lower than $1100 \mathrm{~K}$, the diffusion coefficients of the Ti,
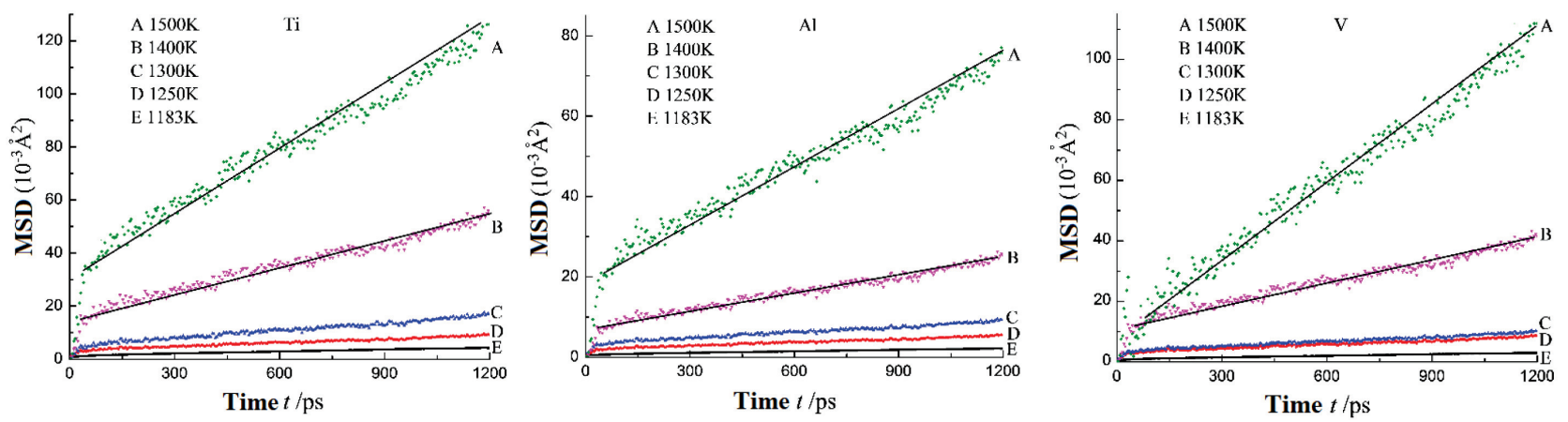

Figure 7: Distribution curve of the MSD with the holding time at different temperatures of the atoms $\mathrm{Ti}, \mathrm{Al}$ and $\mathrm{V}$

Table 2: Diffusion coefficients of $\mathrm{Ti}, \mathrm{Al}$ and $\mathrm{V}$ atoms under different temperatures

\begin{tabular}{|c|c|c|c|c|c|c|c|}
\hline$T(\mathrm{~K})$ & 1000 & 1100 & 1183 & 1250 & 1300 & 1400 & 1500 \\
\hline$D_{\mathrm{Ti}}\left(10^{-14} \mathrm{~m}^{2} / \mathrm{s}\right)$ & $1.7 \times 10^{-5}$ & $6 \times 10^{-4}$ & 4.1 & 5.1 & 12.6 & 50.4 & 83 \\
\hline$D_{\mathrm{Al}}\left(10^{-14} \mathrm{~m}^{2} / \mathrm{s}\right)$ & $3.5 \times 10^{-6}$ & $1.6 \times 10^{-4}$ & 2 & 4.2 & 8.4 & 20.8 & 48 \\
\hline$D_{\mathrm{V}}\left(10^{-14} \mathrm{~m}^{2} / \mathrm{s}\right)$ & $2.3 \times 10^{-5}$ & $6.7 \times 10^{-4}$ & 2.8 & 4.8 & 9.2 & 28 & 90 \\
\hline
\end{tabular}




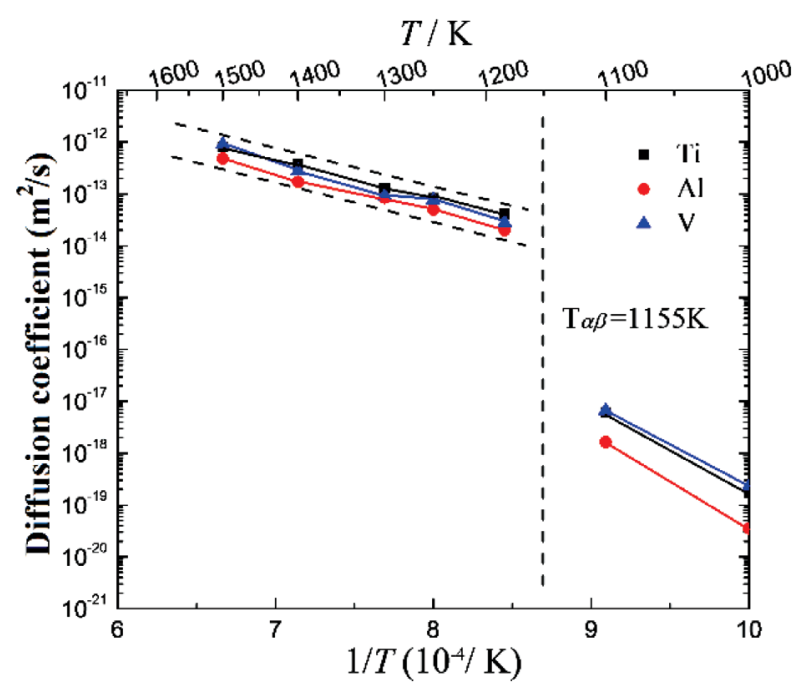

Figure 8: Distribution of the diffusion coefficients of the Ti, $\mathrm{Al}$ and V atoms at different temperatures

$\mathrm{Al}$ and $\mathrm{V}$ atoms are so small that the order of magnitude is about $10^{-19} \mathrm{~m}^{2} / \mathrm{s}$. It shows that the $\mathrm{Ti}, \mathrm{Al}$ and $\mathrm{V}$ atoms are hardly diffusing below $1100 \mathrm{~K}$. This is consistent with the previous conclusion.

Figure 8 shows the curves of the diffusion coefficients of $\mathrm{Ti}, \mathrm{Al}$ and $\mathrm{V}$ in exponential coordinates at the corresponding temperatures. In Figure 8, $T_{\alpha, \beta}=1155$ $\mathrm{K}$ is the transition temperature from phase $\alpha$ to phase $\beta$ in the Ti-6Al-4V alloy. It can be seen from the figure that the diffusion coefficients of the above three atoms increase obviously near the phase-transition temperature. The main reason is that the $\mathrm{BCC}$ structure has more interstitial space than the HCP structure. The diffusion rate of the atoms in the BCC crystal structure is usually higher than that in other crystal structures.

The diffusion coefficient $D$ of the elements depends on the diffusion activation energy $Q$ and the temperature T. $Q$ is defined as the smallest energy that atoms possess when they transit. The Arrhenius equations is satisfied among $D, Q$ and $T$, as shown in Equation (9):

$$
D=D_{0} \exp \left(-\frac{Q}{R t}\right)
$$

where $D_{0}$ is the diffusion-coefficient factor, $R$ is the gas constant, which generally takes .

The Arrhenius equations were fitted to the diffusion coefficients and the temperatures of the Ti, Al and $\mathrm{V}$ atoms (Table 2), respectively, which are shown as:

$$
\begin{aligned}
& D_{\mathrm{Ti}}=4.38 \times 10^{-9} \exp (-13593 / T) \\
& D_{\mathrm{Al}}=3.52 \times 10^{-9} \exp (-14230 / T) \\
& D_{\mathrm{V}}=1.26 \times 10^{-8} \exp (-15769 / T)
\end{aligned}
$$

where the dimensions of the diffusion coefficient and temperature are $\mathrm{m}^{2} / \mathrm{s}$ and $\mathrm{K}$, respectively.

According to Equation (10), the diffusion activation energies of the corresponding atoms in the temperature range from $1183 \mathrm{~K}$ to $1500 \mathrm{~K}$ can be obtained and listed in Table 3, as well as the experimental values in the literature. It can be seen that the diffusion activation energy calculated in the paper shows good agreement

\begin{tabular}{|c|c|c|c|c|c|c|}
\hline \multirow[b]{2}{*}{$\begin{array}{l}\text { Para- } \\
\text { meter }\end{array}$} & \multicolumn{2}{|c|}{$\mathrm{Ti}$} & \multicolumn{2}{|c|}{$\mathrm{Al}$} & \multicolumn{2}{|c|}{$\mathrm{V}$} \\
\hline & $\begin{array}{c}\text { Experi- } \\
\text { mental } \\
\text { data }\end{array}$ & $\begin{array}{l}\text { Simu- } \\
\text { lation } \\
\text { results }\end{array}$ & $\begin{array}{c}\text { Experi- } \\
\text { mental } \\
\text { data }\end{array}$ & $\begin{array}{l}\text { Simu- } \\
\text { lation } \\
\text { results }\end{array}$ & $\begin{array}{c}\text { Experi- } \\
\text { mental } \\
\text { data }\end{array}$ & $\begin{array}{l}\text { Simu- } \\
\text { lation } \\
\text { results }\end{array}$ \\
\hline \multirow{2}{*}{$(\mathrm{eV})$} & 1.49 & \multirow{2}{*}{1.19} & 1.29 & \multirow{2}{*}{1.23} & 1.53 & \multirow{2}{*}{1.36} \\
\hline & 1.35 & & 1.53 & & 1.68 & \\
\hline
\end{tabular}
with the experimental values in the literature. ${ }^{19-21}$

Table 3: Comparison of the calculated diffusion activation energies of $\mathrm{Ti}, \mathrm{Al}$ and $\mathrm{V}$ with the experimental values

\section{CONCLUSION}

The diffusion-bonding process of the Ti-6Al-4V alloy was numerically simulated using the molecular dynamics method. The influence of various process parameters on the diffusion-bonding behavior was studied. The effects of the different holding temperatures on the diffusion behavior of the $\mathrm{Ti}, \mathrm{Al}$ and $\mathrm{V}$ atoms were also investigated. The main conclusions are as follows:

1. Based on the fundamentals of molecular dynamics, the mixed potential function method (the EAM potential and the Morse potential) was used to deal with the potential of the Ti-Al-V ternary alloy system. The diffusion-bonding process of the Ti-Al-V ternary alloy was numerically simulated and good results were obtained. The simulation results showed that the Ti-atom diffusion was dominant in the ternary alloy system.

2. The influence of temperature, pressure and holding time on the diffusion-bonding width was studied. The general trend was that the diffusion-bonding width increases with the appropriate increase of temperature, pressure and holding time, thus improving the quality of the diffusion joints.

3. The atoms at the interface hardly diffused below $1100 \mathrm{~K}$. When the holding time was long enough, the diffusion-bonding width increases first and then decreases slightly with the increase of the temperature. The optimum diffusion-bonding temperature of Ti-6Al-4V alloy was about $1200 \mathrm{~K}$.

4. The diffusion coefficients of the Ti, Al and V atoms change sharply near the transition temperature of the $\beta$ phase to the $\alpha$ phase. The Arrhenius diffusion equation of for the Ti, $\mathrm{Al}$ and $\mathrm{V}$ atoms was established based on the simulation results. The diffusion activation energies of the three types of atoms were deduced from the diffusion equation, which was in good agreement with the experimental results in the literature.

\section{Acknowledgement}

Financial support by the Fundamental Research Funds for the Central Universities (No. NS2016022) and 
National Science and Technology Major Project (2017-IV-0012-0049) are gratefully acknowledged.

\section{REFERENCES}

${ }^{1}$ B. J. Alder, T. E. Wainwright, Phase transition for a hard sphere system, Journal of Chemical Phys, 27 (1957) 5, 1208-1209, doi:10.1063/1.1743957

${ }^{2}$ L. Verlet, Computer 'experiments' on classic fluids, I. thermo-dynamical properties of Lennard-Jones molecules, Health Physics, 22 (1967) 1, 79-85, doi:10.1097/00004032-197201000-00013

${ }^{3}$ C. H. Andersen, Molecular dynamics simulations at constant pressure and/or temperature, Journal of Chemical Physics, 72 (1980) 4, 2384-2393, doi:10.1063/1.439486

${ }^{4}$ D. J. Evans, B. L. Holian, The Nose-Hoover thermostat, Journal of Chemical Physics, 83 (1985) 8, 4069-4074, doi:10.1063/1.449071

${ }^{5} \mathrm{R}$. Car, Unified approach for molecular dynamics and density functional theory, Phys. Rev. Lett, 55 (1985) 22, 2571-2574, doi:10.1103/PhysRevLett.55.2471

${ }^{6}$ M. Grujicic, P. Dang, Atomic-scale analysis of martensitic transformation in titanium alloy with vanadium, Part II: molecular dynamics simulation, Materials Science and Engineering A, 205 (1996) 1-2, 153-165, doi:10.1016/0921-5093(95)09893-3

${ }^{7}$ L. Long, W. Bao-Fen, L. I. Li, Molecular dynamics simulation of diffusion behaviour at the interface of hot rolling-diffusion bonding of Cu/Al, Heat Treatment Technology \& Equipment, 71 (2011) 2, 6122-6131, doi:10.1158/0008-5472.CAN-10-4366

${ }^{8}$ T. Fuling, Z. Jun, B. Hongwei, L. U. Wen, R. Zhi-Yuan, Molecular dynamic simulation of diffusive bonding between Ti-Al and welded joint tensile performance, Journal of Lanzhou University of Technology, 41 (2015) 2, 1-6

${ }^{9}$ L. L. Zhu, Q. Zhang, Z. Chen, C. Wei, G. M. Cai, Measurement of inter diffusion and impurity diffusion coefficients in the bcc phase of the Ti-X ( $\mathrm{X}=\mathrm{Cr}$, Hf, Mo, Nb, V, Zr) binary systems using diffusion multiples, Journal of Materials Science, 52 (2017) 6, 3255-3268, doi:10.1007/s10853-016-0614-0

${ }^{10}$ X. F. Wang, M. Ma, X. B. Liu, J. G. Lin, Interface characteristics in diffusion bonding of a $\gamma$-TiAl alloy to Ti-6Al-4V, Journal of materials science, 42 (2007), 4004-4008, doi:10.1007/s10853-0060189-2
${ }^{11}$ B. Zhang, X. Y. Zhang, L. Chao, K. Z. Zhou, Molecular dynamics simulation on phase transition of Ti-Al alloy with low Al content, Rare Metal Materials and Engineering, 41 (2012) 6, 1010-1015, doi:10.1016/S1875-5372(13)60043-0

${ }^{12}$ R. R. Zope, Y. Mishin, Interatomic potentials for atomistic simulations of the Ti-Al system, Physical Review B, 68 (2003) 2, 366-369, doi:10.1103/PhysRevB.68.024102

${ }^{13}$ A. R. Leach, Molecular Modeling principles and applications, $2^{\text {nd }}$ Ed., Pearson Prentice Hall, (2001), 77-98

${ }^{14}$ P. M. Morse, Diatomic molecules according to the wave mechanics. II. Vibration Levels, Physical Review, 34 (1929) 6, 57-64, doi:10.1103/PhysRev.33.932

${ }^{15}$ Y. L. Liu, J. Z. Bao, L. Zhang, S. Q. Wang, H. Q. Ye, Moleculer Dynamics Study of the Thermodynamic Shear Deformation in TiAl/Ti3Al System, Acta Physical Sinica, 58 (2011) 6, 246-253, doi:10.4028/www.scientific.net/MSF.689.168

${ }^{16}$ Y. Mishin, M. J. Mehl, A. F. Voter, Structural stability and lattice defects in Copper: ab initio, tightinding, and embedded-atom calculations, Physical Review B, 63 (2001) 22, 224106, doi:10.1103/ PhysRevB.63.224106

${ }^{17}$ M. Parrinello, A. Rahman, Polymorphic transitions in single crystals: A new molecular dynamics method, Journal of Applied Physics, 52 (1981) 12, 7182-7190, doi:10.1063/1.328693

${ }^{18}$ F. F. Chen, H. F. Zhang, Z. Q. Hu, Molecular dynamics simulations of diffusion properties of $\mathrm{Cu}$ in supercooled liquid and amorphous state, Acta Metallurgica Sinica, 40 (2004) 7, 731-735, doi:10.1109/JLT.2003.821766

${ }^{19}$ S. L. Semiatin, S. L. Knisley, P. N. Fagin, D. R. Barker, F. Zhang, Microstructure evolution during alpha-beta heat treatment of Ti-6Al-4V, Physical Metallurgy and Materials Science, 34 (2003) 10, 2377-2386, doi:10.1007/s11661-003-0300-0

${ }^{20}$ Y. Mishin, Chr. Herzig, Diffusion in the Ti-Al system, Acta Materialia, 48 (2000) 3, 589-623, doi:10.1016/s1359-6454(99) 00400-0.

${ }^{21}$ T. Takahashi, Y. Minamino, M. Komatsu, Interdiffusion in $\beta$ phase of the ternary Ti-Al-V system, Materials Transactions, 49 (2008) 1 , 125-132, doi:10.2320/matertrans.MRA2007110 